\title{
Socialization of Technologies and Network-Based Welfare of Older Adults in Russia
}

\author{
Gasanov M.A. ${ }^{\text {** }}$, Ermushko Zh.A. ${ }^{\mathrm{a}}$, Zhavoronok A.V. ${ }^{\mathrm{a}}$ \\ * Corresponding author: Gasanov M.A., hursyd1@yandex.ru \\ ${ }^{a}$ Institute of Social and Humanitarian Technologies, National Research Tomsk Polytechnic University, 30, Lenina av., Tomsk, \\ 634050, Russia
}

\begin{abstract}
http://dx.doi.org/10.15405/epsbs.2016.02.44

Socialization of technologies the least studied area of interdisciplinary scientific knowledge. Authors investigate a scientific problem of information-technological revolution's interrelation and social structure of the Russian society. Impact of cardinal demographic shifts on dynamics and structure of continuous well-being is revealed, the new structure of needs of elderly people is classified. New interpretation of the emotional status and networkbased welfare of the person in the Russian society as an assessment of personification of psychological perception of reality and synergetic effect from socialization through network technologies is offered. Need of integration of elderly people into Internet space for the purpose of expansion of social opportunities limits of self-identification and realization of many-sided segments of human potential is proved.
\end{abstract}

(C) 2016 Published by Future Academy www.FutureAcademy.org.uk

Keywords: Emotional status, network-based welfare, sovereignty of older adults, social shifts, informational and technological revolution, socialization of technologies.

\section{Introduction}

Convergence of various directions of scientific research, intensity of transfer and expansion of information technologies have key impact on all parties of modernization of Russian society and their consequences are shown in transformation of society's social structure, serious changes in age structure, in professional and general educational level, in public consciousness of older adults. Market's formation in Russia was followed by radical changes in social life of people and it caused second thoughts of their role and place in society, especially criteria of well-being of older adults. Mass availability and powerful intervention of technologies into private space of people became the main stream; social orientation of introduction of technologies becomes a key factor of network and 
eISSN: 2357-1330

Selection \& Peer-review under responsibility of the Conference Organization Committee

continuous well-being of a person. Networks virtualize social activity, there is a formation of a cyberspace.

Older adults are the most socially vulnerable group of the population. They need a guaranteed decent life and health care. The unprecedented demographic changes associated with increase of longevity are observed in the 21 st century all over the world. The aging of population is the key trend since older adults (aged 60 years or older) will make up more than one fifth of the total world population (22\%). Their number will reach 2.03 billion people against 809 million at the present time (11\%). (International Rating)

In Russia, the informational and technological revolution is clearly associated with the highly intensive modernization processes and computerization of households which entail increasing expenses for additional individual goods and services. Costs for searching and acquiring information and "transactions costs" in general are expected to grow further (Coase, 1937). The opportunities of increasing the information industry in Russia will be implemented quickly. The introduction of information technologies in all areas of the social and economic life will go beyond the relatively moderate limits.

\section{Methodology and research sources}

The well-being of older adults depends on a number of factors, including the volume of social payments by the state, the development of non-state pension system and the level of information technologies spread in society. These factors depend directly on the level of development of modern technologies and their mass use. However, social payments (pensions, benefits, etc.) are less sensitive to progress in information technologies. On the contrary, the information technologies are generated by progress and have huge perspectives to increase the level of satisfaction of older adults. We believe the development of the convergence of information and social technologies to be a key point in improving the emotional status of older adults. We researched the ways of socialization of technologies and network-based well-being development on the examples of the United States, Germany and Russia.

\section{Results and discussion}

\section{Emotional Status as the Integral Welfare Index}

The rapid aging of the population in general and high labour activity of older adults in particular result in intense aging of workforce. Even today, middle and elderly-aged employees prevail in the labour market (State Statistics), which is confirmed by the monitoring of the socioeconomic status of older adults in Russia (Monitoring of the Socioeconomic Status). In 2013, older adults of working age reached the employment level of $29.2 \%$. This trend demonstrates a shortage of high-level specialists among younger adults and a deficit of highly skilled specialists in Russia in general.

The deficit of highly skilled human resources can be significantly softened by enhancing health and working ability of the working population (15-60 years), as well as by creating decent work conditions for older adults (60-80 years) (Krutko, 2014). 
The IT-developments in Russia has improved the living conditions of older adults to a certain degree. Such improvements concern nutrition, clothes, durable goods, health support, housing conditions, transport services, social security and medical care, environmental condition. As a result, the balance of satisfied essential needs of older adults was achieved. The welfare of older adults is the integral assessment of all life aspects which shows how "well" they have lived in a certain period of their life (Korneychuk, 2006).

In our opinion, assessment of their welfare should be based on the whole set of socioeconomic indicators that reflect its essential qualities in a varying degree. However, we suppose that the emotional status as fixed subjective information is the subjective reflection of a personal sense of happiness and peace, mental and emotional comfort of an individual. The growth of income and consequent improvement of older adults' life have facilitated the significant strengthening of consumer sentiment, the gradual departure from the traditional values oriented at saving and austerity, as well as the clear destruction of collective identity, development of individualization and self-actualization (Voytov, 2000). The emotional status is structured by integral indicators, factors of the institutional environment, and features of the psycho-emotional space. The network technologies and the opportunities of the global network Internet play a key role in enhancing the emotional status in Russian society.

\section{Network-Based Welfare of Older Adults}

The actualization of the socioeconomic problems associated with the expanding informational and technological revolution has given rise to a new approach to the objectives of the national socioeconomic policy. Under the current conditions, this policy has the following key aspects related to the social welfare: 1) "welfare programs" (in the narrow sense of this word - the social security and insurance system) 2) system of social services and public housing construction; 3) business cycle policy and government regulation of economic growth; 4) environmental management.

The social security system includes five basic types of programs under which monetary benefits and medical services are provided: 1) retirement, disability and survivor's benefits; 2) sickness and maternity benefits; 3 ) employment injury benefits; 4) unemployment benefits; 5) family benefits.

In the context of new industrialization, Russia needs to initiate "socialization" of its legal, largescale social reforms at the national government and corporate level. Corporate welfare programs (pension funds, group forms of insurance) play a significant role as an additional tools for attracting highly skilled specialists, including older adults: a tool for tying them to a company; a method to improve "human relations", the partnership environment; a tool of publicity and promoting the "social face" of a company.

A number of large companies in Russia strive to use non-monetary tools to stimulate their employees for more efficient work, try to enhance their loyalty and commitment to corporate ideals through socialization of employee-employer relations. The most common tool of such a policy is the non-government pension security system which has been rapidly developing in Russia. A certain part of large business companies have signed agreements for additional pension security for their employees with non-government pension funds and often create their own funds. This has allowed 
them to improve motivation for work, to increase future retirement benefits and to save on taxes since the funds directed to non-government pension funds for additional security of their employees are not subject to the individual income tax. In general, the quality of older adults' life is increasing. This is confirmed e.g. by the dynamics of the Global AgeWath Index calculated by the international nongovernmental organization "HelpAge International" jointly with the United Nations Fund for Population Activities (UNFPA). At this stage, the study covers 96 countries for which the internationally comparable statistical data are available. These countries make up $90 \%$ of the world's population aged 60 years or older (Global AgeWath Index, 2014). According to the study, in 2014 the Global AgeWath Index of Russian older adults increased by 13 points as compared with 2013, Russia jumped from the 78 th place to the 65 th one.

There are several parameters of the emotional status. Firstly, older adults show a significantly greater demand for high-quality, environmentally sound and vitamin-rich food products. Greater availability of food products is a positive parameter of its quality assessment. Secondly, among nonfood products the priority is given to a wide range of electronic devices and clothing made of natural fabrics. New technologies are finding their way to the personal consumption sector and give rise to the real technological revolution in this area. Thirdly, the requirements for quality housing as the priority value are significantly increasing. Fourthly, various services (information, tourist, etc) satisfying needs of older adults play an important role in the personal consumption structure. Fifthly, the requirements for life quality and conditions of older adults are increasing as well. Sixthly, the response to the environmental situation and pollution is becoming stronger.

All these aspects shape a new model, the modified personal consumption structure for older adults. We define this process as the socialization of the emotional status in the network economy. It entails additional costs for purchasing goods and services of higher quality, improvement of living conditions, and enhancement of the environmental comfort. In the context of the network-based welfare, the technological structure of older adults' personal property and the utility maximization patterns are considerably changing. The needs of older adults are constantly growing and act as the incentive and impetus to widening a range of products and services, to improving their quality and quantity.

With the development of market economy and strengthening the role of information technologies in Russian society, the information needs associated with new opportunities are growing and giving a rise to a new human model which is more typical for the network society. These ideas are reflected in some socioeconomic studies (Etzioni, 1991) (Swedberg, 1987). The development of the network space is clearly a key IT trend which naturally represents the most advanced directions of social virtualization.

Nowadays, the wide access to information provides more opportunities to older adults, and the utility maximization is achieved at a higher level of its satisfaction. In the context of the transition to the information society, "the task to produce essential goods is becoming a trivially simple due to the technological progress and the economic development (Kahn \& Brown, 1995). The information needs begin to dominate in the coordinates of the information society: "they can be satisfied through activities of such sectors that are capable to provide information facilitating extension of knowledge, growth of human creativity, and enrichment of personal culture" (Laichuk \& Nikolayeva, 2009). 
http://dx.doi.org/10.15405/epsbs.2016.02.44

eISSN: 2357-1330 / Corresponding Author: Gasanov M.A., Email: hursyd1@yandex.ru

Selection and peer-review under responsibility of the Organizing Committee of the conference

Various information flows have become an indispensable element of older adults' everyday life. The global use of Internet is the evidence of IT-development in the life of contemporary society. Information available via Internet is universal. The synthesis of cybernetics and telecommunications (via phone, TV, satellite) create prerequisites and conditions for the fundamental enrichment of collective, group and individual information activity, as well as for broadening the social interaction. The opportunities for developing the network-based welfare of older adults are associated with the further technological improvement of Internet technologies, their transformation into more efficient advanced trends of social networks.

The socioeconomic changes in Russia have created the open society and information abundance. It is the first time for many years that older adults have a choice of information. Nowadays, over a half of Russian households are connected to Internet. More comfortable information conditions have been provided to these citizens. In addition to the possibility of receiving digital TV programs of higher quality, they are provided with a lot of diverse information services, including news and announcement, schedules for all means of transport, medical consultations, commercial advertisements, and other pragmatic data. The combination of information into the unified "guide" will ensure the quick and easy access to information about goods and services. Internet not only assumes many functions of the market but also integrates them with other functions: 1) identification, order and purchase of goods and services; 2) making all financial settlements; 3 ) support of business and personal relations; 4) work and study based on the concept of continuous learning; 5) arts and hobbies; 6) virtual travelling in the cyberspace; 7) entertainment. Among older adults who use a smartphone (i.e. a phone connected to the mobile Internet) at least for one week, only a negligible number return to conventional cell phones (i.e. only for calls and SMS). This suggests that they change their consumption model for telecommunication services and create a new comfort zone which is not easy to leave. It is very difficult to imagine that a user of mobile communications will reject such important opportunities - to have almost all knowledge available to the humanity: from online encyclopedia to art collections of the world best museums. He will not reject a lot of conveniences - to lay rapidly a route from A to B in an unknown territory, to pay community charges not leaving home, to watch a match of his favorite team or a popular serial if he has no time to watch it on TV set. And this is only a few examples of how the mobile Internet can make the life of any human being more bright, interesting and comfortable.

Taking this into account, producers of smartphones have launched a line of special gadgets for older adults. Their interface is specially designed to be convenient in use by this category of citizens. This demonstrates that the qualitative shifts are becoming more and more tangible - mainly due to the fact that Internet, mobile phones and digital technologies offer new opportunities to older adults. It can be said that patterns of using different new information sources are crucially changing and, equally, time consumed for mass communication is evidently increasing (Shastitko, 2006). Here, the expanding capabilities of older adults are becoming an inexhaustible resource (Vartanova, 2003).

The emotional status of older adults is intimately connected with intensity, synchronicity, mobility, and publicity of information in Internet. It substantially enriches the information basis for many everyday activities in various areas of the family life. It enriches family and interpersonal relations which are typical for older adults' life. 
The network expectations of older adults encompass a diversity of wishes: to know more about the history of their community, region, country, world, etc.; to share opinions about books they have read; to take advice from experienced people; to take classes in housekeeping, horticulture, floriculture, arts and other useful crafts; to watch online sessions of the local government and parliament; to learn foreign languages; to consult with physicians and take advice for medical treatment and disease prevention; to acquire skills in using personal computers, mobile phones, and tablets; to take part in online tournaments and competitions (e.g. various games); to watch regularly special TV programs aimed at resolving conflicts and facilitate mutual understanding between generations; to enjoy documentary films about history, conventional and contemporary art and culture in Russian and other countries, etc.

Nowadays, there are special network resources designed for older adults. For example, the social network Strana Pensioneriya has been created and is successfully functioning. Older adults willingly share information and experience on a wide variety of topics: online earning options and using specialpurpose software, travelling to different countries and discussion of fashion for older adults, etc.( Social network, 2015). Nevertheless, the opinion that Internet is an essential need for older adults is still not common in Russia, although foreign countries have finally settled this problem long ago (Online Magazine, 2015). All civilized western countries have dozens of websites and social networks for older adults. This is also the same for Eastern countries. For example, the Chinese search engine Baidu.com launched the special version for older users. It differs from the "basic" Baidu both by design with bigger fonts and content. The website contains links to different sections such as classical poetry, revolutionary songs, calligraphy, poultry breeding, etc. - everything which is traditionally interesting to the older part of Chinese society. Chinese people over fifty years make up less than $5 \%$ of network users. However, Baidu offers services to different groups of users - poor-sight persons, children, older adults.

Among all other things, one of the key demands shown by older adults for network technologies is associated with the interest in genetically modified organisms (GMO) and genetically modified food products. It is no secret that older adults in Russia make up the bulk of households involved in family farming and creating a demand for seeds and tillage equipment. On the one hand, the modern technologies in this area - biotechnologies - are the elements of cropping farms, but, on the other hand, there is a great information vacuum related to safety of using them in agriculture. An increasing number of retirees and aging of the population aggravate this problem since the welfare of older adults is associated with the possibility to engage themselves in labour and to provide themselves and their families with safe food. This is often connected with tillage and growing food in their own (private) land plots.

An increasing demand for network information technologies is partially explained by distribution of information about risks of using GMOs in food production. In particular, the studies of professor Seralini shock with their conclusions: he has proved that test rats receiving genetically modified maize face some serious health problems (GMOSeralini:, 2015).

In addition to the strong evidence of Seralini that GMOs may be hazardous for food production, there are many other negative consequences from increasing the use of genetically modified organisms 
http://dx.doi.org/10.15405/epsbs.2016.02.44

eISSN: 2357-1330 / Corresponding Author: Gasanov M.A., Email: hursyd1@yandex.ru

Selection and peer-review under responsibility of the Organizing Committee of the conference

in the food industry: reduction of plant biodiversity; chemical pollution of fertile soils because of increasing herbicide volumes and concentrations; risks of higher GMO-specific mutagenic activity.

The welfare of older adults is equally associated with access to high-quality and health food, hightechnology medical care, reduction of disease risks, and access to information which allows them to minimize some risks. Such minimization may be connected with the possibility to control some negative trends resulting from the increasing scientific and technological progress in a number of specialized branches or, at least, to be aware of the latest scientific achievements and risks of introducing them into the real economy.

Using the network technologies and generating queries to the network space, older adults have the opportunity to satisfy a bulk of such queries. The practice shows that older adults consistently consider Internet as the means of dialogue, bidirectional communications between individuals acting as an independent party or an intermediary between the population and local authorities. Older adults think that Internet is the important source of local information, regional historical studies, medical knowledge, and practical health data. A share of Internet users among older adults is a quite considerable parameter. Internet facilitates the distribution of cultural information, the increase of the cultural and educational level, personal enrichment of older adults; acts as a tool for developing interests (hobbies) and acquiring practical skills; activates a participation in local self-government; has great benefit for education of children. Finally, Internet develops contacts between older adults, especially in the immediate, neighboring environment (new acquaintances, new subjects and topics for discussion, showing more attention to each other, exchange of greetings in the street, etc.). The ease of access and information requests makes Internet a very efficient and promising mass service for older adults.

\section{Conclusion}

New technologies are finding their way into everyday lives of older adults and, even at early stages, getting the all-round support from the government, private firms and non-profit organizations. Searches for efficient social technological solutions are based on economic factors. An increasing competition, the need to stimulate the individual and aggregate demand for innovative technologies push all entrepreneurs to act more efficiently. Their strategies are based on the attempts to free information processes from the fundamental imperatives of the socioeconomic development. It cannot be said that information technologies are capable to change drastically the basic socioeconomic attitudes of older adults, but some positive shifts are evident.

Older adults represent the disadvantaged part of Russian society - more educated but less well-off than the other part of the population. Their social and cultural privileges have the direct influence on the content and structure of their information needs, on the motivation to use new technologies. Older adults are the more democratic group and better serve the purposes of the information society. As long as the retirement insurance is used as a tool for simple reproduction of labor-power, the restrictions associated with a slow growth of social and cultural needs will remain. 
Therefore, the development of the information society in Russia has the direct influence on degree of emotional comfort and enhanced emotional status of older adults, as well as the possibility to participate in various network activities.

The authors of this study suppose that the concept of emotional status institutionally clears up the concept "general welfare of older adults" and is especially beneficial for criterial reasoning of the latter one.

The key peculiarities and criteria of the emotional status include personification which is combined with the most tangible and sensible form of perception - the subjective perception. The subjective perception is a certain integral indicator which is eventually determined by the emotional status itself, i.e. expresses all aspects of the individual's life satisfaction.

The research contribution of the authors is the attempt to summarize the methods for identifying the emotional status and the tools enriching its etymological status. It is not intended to be exhaustive. We are willing to share experience to consolidate efforts in studying such a complex phenomenon as the network-based welfare and the emotional status of older adults and, therefore, to gain an understanding of similarities and differences of these concepts and their real implications in various places of the world.

\section{Acknowledgements}

This work was performed by the authors in collaboration with Tomsk Polytechnic University within the project in Evaluation and enhancement of social, economic and emotional wellbeing of older adults under the Agreement No.14.Z50.31.0029.

\section{References}

International Rating for Global AgeWath Index. Center of Human Technologies. Available at http: //qtmarket. $\mathrm{ru} /$ ratinqs/qlobal -aq-e wath-index/info

Coase R.H. (1937)The Nature of the Firm. Economica, New Series, 4 (16), 386-405. Available at : http://www.colorado.edu/ibs/eb/alston/econ4504/readings/The\%20Nature\%20of\%20the\%20Firm\%20by\% 20Coase.pdf

Gosudarstvennyj komitet po statistike Rossijskoj Federacii (Rosstat) (State Statistics Committee of the Russian Federation). Available at : http://www.gks.ru/bgd/regl/B11_04/IssWWW.exe/Stg/d03/2-rin-trud.htm

Ministerstvo truda i social'noy zashchity Rossiyskoy Federacii. Monitoring socio-ehkonomicheskogo statusa pozhilyh lyudey. Rezul'taty. (Ministry of Labour and Social Protection of the Russian Federation. Monitoring of the Socioeconomic Status of Older Adults: Results). Available at : http://www.rosmintrud.ru/docs/mintrud/protection/93

Krutko V. (2014) Innovacionnyy put' resheniya demograficheskih problem v Rossii (The Innovative Path to Address the Demographic Problems in Russia) Problemy teorii i praktiki upravleniya.. No. 2, pp. 58-62.

Korneychuk B.V. (2006) Informacionnaya ehkonomika. - Sankt-Peterburg: Piter, 2006 (Information Economics. Saint-Petersburg: Piter, 2006.)

Voytov A.G. (2000) Ekonomika. - Moskva: Marketing, 2000. (Economics. Moscow: Marketing, 2000).

Center of Human Technologies. Helpage International: Global AgeWath Index in 2014. Available at : http://gtmarket.ru/news/2014/10/02/6909

Etzioni A. (1991) Socio-Economics: Toward a New Synthesis/ Lawrence R. eds. Armonk; New York; London: M.E. Sharpe, Inc., pp. 347-359.

Swedberg R. (1987) Econoimic Sociology: Past and Present. Current Sociology. 35, p. 12-21.

Herman Kahn, William Brown, and Leon Martel. (1995) The next 200 years: A Scenario for America and the World the USA - Canada: Economy, Policy, Culture. 2, 96-99.

O.V. Laichuk, L.A. Nikolayeva. (2009) Intellektual'nyy i informacionnyy potencial: voprosy teorii i praktiki. Irkutsk: Izdatel'stvo Baykal'skogo gosudarstvennogo universiteta ehkonomiki i prava (Intellectual and Information Potential: Theory \& Practice. Irkutsk: Publishing House of the Baikal State University of Economics and Law) 
http://dx.doi.org/10.15405/epsbs.2016.02.44

eISSN: 2357-1330 / Corresponding Author: Gasanov M.A., Email: hursyd1@yandex.ru

Selection and peer-review under responsibility of the Organizing Committee of the conference

A.E. Shastitko. Modeli cheloveka v ehkonomicheskoy teorii. - Moskva: INFRA-M (Human Models in Economics. Moscow: INFRA-M), 2006. 142 pp.

E.L. Vartanova Media Economics of Foreign Countries. Moscow: Aspekt Press, 2003. 335 pp.

Social network "Strana Pensioneriya" Available at: http://www.pensionerka.com/

Internet dlya starshego pokoleniya ili starshe pokolenie dlya Interneta // Internet-zhurnal «Tretiy vozrast» (Internet for the Older Generation, or the Older Generation for Internet?) // Online Magazine Tretiy Vozrast. Available at: http://www.3vozrast.ru/article/society/problem/4625/

GMOSeralini: Research Documents, Available at: http://www.gmoseralini.org/ 